\title{
CYBERSTALKING DI TWITTER @TRIOMACAN2000 PADA PEMILU 2014
}

\author{
Christiany Juditha \\ Balai Besar Pengkajian dan Pengembangan Komunikasi dan Informatika (BBPPKI) Makassar \\ J1. Prof.Dr. Abdurahman Basalamah II No. 25 Makassar, 90123, telp/fax: 0411-4460084. \\ Email: christiany.juditha@kominfo.go.id \\ Naskah diterima tanggal 16 Februari 2015, direvisi tanggal 12 Mei 2015, disetujui tanggal 22 Juni 2015
}

\section{CYBERSTALKING ON TWITTER @TRIOMACAN2000 AT ELECTION 2014}

\begin{abstract}
The use of Twitter is open up the space for freedom of expression and opinion. But also raised a new phenomenon called cyberstalking (bullying). Acts of bullying (violence/intimidation) are also occur in cyberspace. People are free to commit violence and intimidate others without either use a personal account, institutional and anonymous. Especially when the Election arrives. This action is more intense uncontrolled. This study was carried out to get an overview of the phenomenon of cyberstalking on Twitter in 2014 elections that carried the account @ TrioMacan2000. The method used is a qualitative content analysis of the unit of analysis is the whole message (tweet) on account @ TrioMacan2000 during the legislative election campaign period opens March 16 to April 5, 2014. The study concluded that most of the tweets are also pictures posted on the account @ TrioMacan2000 throughout the campaign period of election legislation, cyberstalking entered in all categories studied, namely the desire to hurt; post power imbalance; repetition, as well as the pleasure that is felt by the perpetrators.
\end{abstract}

Keywords: bullying, cyberbullying, cyberstalking, twitter, @TrioMacan2000,election.

\begin{abstract}
Abstrak
Penggunaan twitter ini tidak hanya membuka ruang akan kebebasan berekspresi dan berpendapat. Namun juga melahirkan fenomena baru yaitu cyberstalking (bullying). Aksi bullying (kekerasan/mengintimidasi) kini juga terjadi di dunia maya. Orang bebas melakukan kekerasan dan mengintimidasi pihak lain tanpa rasa bersalah baik menggunakan akun pribadi, institusi maupun anonim. Apalagi pada saat pemilihan umum. Aksi ini makin marak dan tidak terkendali. Penelitian ini dilakukan untuk mendapatkan gambaran tentang fenomena cyberstalking di twitter pada Pemilu 2014 yang dilakukan akun @TrioMacan2000. Metode penelitian yang digunakan adalah analisis isi kualitatif dengan unit analisis adalah seluruh isi pesan (tweet) pada akun @TrioMacan2000 selama masa kampanye terbuka Pemilu Legislatif 16 Maret - 5 April 2014. Hasil penelitian menyimpulkan bahwa sebagian besar tweet juga gambar yang diposting di akun @TrioMacan2000 sepanjang masa kampanye pileg, masuk dalam seluruh kategori cyberstalking yang diteliti, yaitu keinginan untuk menyakiti; ketidakseimbangan kekuatan postingan; pengulangan atau repetisi; serta kesenangan yang dirasa oleh pelaku.
\end{abstract}

Kata kunci: cyberstalking, bullying, twitter, @TrioMacan2000, pemilu. 


\section{PENDAHULUAN}

Media sosial mengalami perkembangan yang sangat signifikan dari tahun ke tahun. Indonesia disebut-sebut sebagai negara pengguna media sosial paling aktif, dan paling besar jumlahnya. Salah satu penyebabnya adalah karena harga smartphone (telepon seluler pintar) semakin terjangkau semua kalangan. Pasar smartphone pada 2013 tumbuh sebanyak $44 \%$ atau setara pertambahan 40.000 unit. Dari seluruh warga negara ini yang memiliki ponsel (telepon seluler), 15 persennya memunyai smartphone. Data Global Web Index Survei juga menegaskan bahwa Indonesia merupakan negara yang warganya paling tergila-gila dengan media sosial. Persentase aktivitas media sosial Indonesia mencapai 79,72\%, tertinggi di Asia, mengalahkan Filipina, Malaysia, dan Cina (Mohamad, 2013).

Ada lima media sosial yang paling banyak digunakan masyarakat Indonesia, yaitu facebook, twitter, friendster, linkedin, dan path. Penggunaan media sosial yang makin tinggi juga dikuti dengan lahirnya kebebasan berekspresi dan berpendapat. Pengguna media sosial seakan menemukan ruang untuk mengemukakan apa saja yang mereka pikirkan dan rasakan. Namun, hal ini juga menimbulkan fenomena baru yang dikenal dengan nama cyberstalking. Istilah cyberstalking tidak setenar cyberbullying. "Namun cyberstalking merupakan bagian dari cyberbullying, sehingga pada prinsipnya tidak dibedakan, karena hasil atau akibat dari perbuatan cyberstalker adalah cyberbullying juga. Hanya saja, biasanya orang menggunakan istilah cyberbullying untuk tindakan bullying secara online dengan target atau pelaku adalah para anak dan remaja. Sedangkan cyberstalking lebih ditujukan pada orang dewasa (Valentino, 2013).

Aksi bullying (kekerasan, paksaan untuk menyalahgunakan atau mengintimidasi) tidak hanya dilakukan di dunia nyata saja, namun juga di dunia maya. Bullying yang paling marak saat ini adalah lewat media sosial. Kejahatan yang terjadi dalam konteks media sosial ini terbatas pada bullying secara verbal seperti perang kata-kata, mengirim pesan berupa hinaan atau ancaman, menyebarkan gosip, membuat akun palsu target dan melakukan aktivitas seperti update status, mengirim pesan atau komentar yang merusak nama baik target, mengunggah informasi pribadi target tanpa izin, dan masih banyak lagi aksi lainnya.

Cyberstalking dianggap lebih mudah dilakukan daripada kekerasan konvensional karena si pelaku tidak perlu berhadapan muka dengan orang lain yang menjadi targetnya. Mereka bisa mengatakan hal-hal yang buruk dan dengan mudah mengintimidasi korbannya karena mereka berada di belakang layar komputer atau menatap layar telepon seluler tanpa harus melihat akibat yang ditimbulkan pada diri korban. Hal ini pula yang digunakan sekelompok orang menjelang Pemilu 2014. Mereka dengan gencarnya membuat statussatus yang bersifat membully calon presiden tertentu.

Menjelang pemilu, baik pemilu legislatif maupun presiden, akun @TrioMacan2000 ini kembali bereaksi melakukan political bullying melalui twitter. Akun ini secara terbuka dan tanpa segan menyudutkan orang-orang tertentu, dalam hal ini calon-calon presiden. Tweet-tweet ataupun gambar-gambar yang disertai keterangan yang mengejek korban diposting akun ini merupakan isi pesan yang dikaji dalam komunikasi. Karena itu, masalah ini menarik untuk diteliti dengan rumusan masalahnya sebagai berikut: "Bagaimana isi tweet cyberstalking pada Pemilu 2014 di akun twitter @TrioMacan2000?” Adapun tujuan penelitian ini adalah untuk mendapatkan gambaran tentang isi tweet cyberstalking pada pemilu 2014 di akun twitter @TrioMacan2000.

\section{LANDASAN KONSEP}

\section{Penelitian Terdahulu}

Penelitian-penelitian

tentang cyberstalking, memang banyak dilakukan. Salah satu di antaranya yang dilakukan Hensler dan McGinnis (2008) dengan judul 
Cyberstalking Victimization: Impact and Coping Responses in a National University Sample, dengan jumlah responden 452 orang. Hasil penelitian menunjukkan bahwa pengalaman hampir setengah (46\%) dari responden memenuhi kriteria hukum sebagai korban cyberstalking, yaitu mengalami trauma psikologis, penurunan fungsi akademik/karir, dan prediktor signifikan.

Penelitian lain juga dilakukan oleh Harvey (2003) dengan judul Cyberstalking and Internet Harassment: What the Law Can Do. Penelitian ini membahas masalah cyberstalking dan pelecehan internet dan apa hukumannya bagi pengguna internet jika dihadapkan dengan bentuk perilaku ini di Selandia Baru. Hasil penelitian mengungkapkan pelecehan online ini mirip dengan yang terjadi di dunia nyata sehingga undang-undang dan hukum umum dapat digunakan untuk menangani masalah pelecehan online.

Perbedaan beberapa penelitian yang telah disebutkan di atas dengan penelitian yang dilakukan peneliti di sini, adalah dari sisi ranah dan metode penelitiannya. Jika penelitian-penelitian sebelumnya banyak mengkaji cyberstalking dari ranah psikologis dan hukum dengan menggunakan metode survei dan observasi, penelitian ini berada di ranah komunikasi yang mengkaji isi pesan (tweet) 'bullying' yang dilakukan oleh pelaku cyberstalking serta menggunakan metode penelitian analisis isi kualitatif.

Istilah bullying belum banyak dikenal masyarakat, terlebih karena belum ada padanan kata yang tepat dalam bahasa Indonesia. Beberapa istilah dalam bahasa Indonesia yang seringkali dipakai masyarakat untuk menggambarkan fenomena bullying di antaranya adalah penindasan, penggencetan, perpeloncoan, pemalakan, pengucilan, atau intimidasi (Susanti, 2006). Bullying juga diartikan sebagai suatu kejahatan. Rigby (2005) menyebutkan bahwa unsur-unsur yang terkandung dalam pengertian bullying antara lain keinginan untuk menyakiti, tindakan negatif, ketidakseimbangan kekuatan, pengulangan atau repetisi, bukan sekadar penggunaan kekuatan, kesenangan yang dirasakan oleh pelaku, dan rasa tertekan di pihak korban.

Dari beberapa definisi bullying di atas dapat disimpulkan bahwa bullying merupakan bentuk tindakan kekerasan yang repetitif, cenderung diulang, dilakukan berkali-kali atau terus menerus selama periode waktu tertentu.

\section{Cyberbullying dan Cyberstalking}

Pengertian bullying yang terjadi dunia nyata sama dengan yang terjadi di dunia maya (internet), yang membedakan hanyalah media yang digunakan. Definisi cyberbullying, menurut The National Crime Prevention Council sebagai proses menggunakan internet, ponsel atau perangkat lain untuk mengirim teks atau gambar yang dimaksudkan untuk menyakiti atau mempermalukan orang lain. Cyberbullying bisa dilakukan dengan posting rumor atau gosip tentang seseorang di internet yang bisa saja membawa kebencian dalam pikiran orang lain terhadap target, atau dapat dengan cara membeberkan identitas pribadi target untuk mempermalukannya (Valentino, 2013).

Cyberstalking merupakan bagian dari cyberbullying. Menurut Bocij (2004), cyberstalking adalah penggunaan internet atau alat elektronik lainnya untuk menguntit atau melecehkan individu, sekelompok individu, atau organisasi. Termasuk melakukan tuduhan palsu atau pernyataan fakta palsu (seperti dalam pencemaran nama baik), pengintaian, ancaman, pencurian identitas, merusak data atau peralatan target/korban.

Kebanyakan pelaku cyberstalking adalah orang yang dikenal (paling tidak pernah berinteraksi), namun ada juga pelaku anonim yang melakukan hal ini karena permintaan si stalker itu, tetapi intinya otaknya adalah si cyberstalker yang pernah atau memang dikenal. Taktik yang umum digunakan oleh cyberstalkers dilakukan dalam forum publik, media sosial atau situs informasi online dan dimaksudkan untuk mengancam korban, merusak reputasi, merusak pekerjaannya, atau keselamatannya. Pelaku juga dapat mendorong orang lain 
untuk melecehkan korban dan berusaha untuk memengaruhi partisipasi secara online (memengaruhi orang banyak) untuk memusuhi, melukai, melecehkan korban.

\section{Twitter Dipakai sebagai Media Cyberstalking}

Twitter adalah layanan jejaring sosial dan mikroblog daring yang memungkinkan penggunanya untuk mengirim dan membaca pesan berbasis teks hingga 140 karakter, yang dikenal dengan sebutan kicauan (tweet). Twitter didirikan Maret 2006 oleh Jack Dorsey, dan situs jejaring sosialnya diluncurkan pada Juli 2006. Sejak diluncurkan, twitter telah menjadi salah satu dari sepuluh situs yang paling sering dikunjungi di internet, dan dijuluki dengan pesan singkat dari internet (D'Monte, 2009).

Menurut layanan penelitian pasar yang meneliti perilaku web dan media sosial, Global Web Index (GWI), situs mikrobloging twitter hingga akhir 2012 tercatat sebagai platform sosial dengan pertumbuhan paling pesat di dunia. Jumlah pengguna aktif twitter tercatat tumbuh 40 persen di kuartal kedua hingga kuartal keempat 2012. Itu artinya setara dengan 288 juta pengguna aktif per bulannya (Putra, 2013). Tingginya popularitas twitter menyebabkan layanan ini telah dimanfaatkan untuk berbagai keperluan dalam berbagai aspek, misalnya sebagai sarana protes, kampanye politik, sarana pembelajaran, dan sebagai media komunikasi darurat (Thompson, 2009).

Sayangnya, media sosial dengan pertumbuhan paling pesat ini juga digunakan untuk melakukan bullying. Berbagai kasus bunuh diri akibat bullying di twitter terjadi. Di antaranya kematian artis dan pembawa acara terkenal Australia, Charlotte Dawson Februari 2014 yang sering merefleksikan depresi akibat meningkatnya insiden bullying melalui situs media sosial (Admin, 2014). Kisah miris ini menjadi sebuah pelajaran penting bagi siapa pun. Perilaku bullying yang dilakukan, baik di dunia nyata maupun dunia maya (online), rupanya sama menyakitkannya bagi korban. Penghinaan secara terus menerus, menyalahkan, merendahkan, dan intimidasi yang membuat hilangnya kepercayaan diri seseorang memiliki dampak yang sangat buruk dan berbahaya.

\section{METODE PENELITIAN}

Metode yang digunakan dalam penelitian ini adalah analisis isi. Wimmer dan Dominick dalam Kholil (2006) mengartikan analisis isi sebagai suatu posedur yang sistematis yang dirancang untuk menguji isi informasi yang direkam. Menurut Kriyantono (2008), Analisis isi kualitatif merupakan suatu analisis isi yang lebih mendalam dan detail untuk memahami produk isi media dan mampu menghubungkannya dengan konteks sosial/realitas yang terjadi sewaktu pesan dibuat.

Adapun unit analisis riset ini adalah seluruh isi pesan (tweet) pada akun @ TrioMacan2000 selama masa kampanye terbuka Pemilu Legislatif 16 Maret - 5 April 2014. Penentuan sampel diambil secara acak sesuai kategori yang diteliti. Alasan pemilihan akun @TrioMacan2000 karena akun ini dikenal sebagai akun anonim dan paling sering melakukan tindakan bullying terhadap pihak-pihak tertentu yang berhubungan dengan kekuasaan.

Data yang terkumpul kemudian dikomparasikan dengan hal-hal yang berkaitan dan pemilihan kunci-kunci perbedaan yang muncul dalam setiap kategori atau item teks. Kesemuanya ini kemudian dianalisis sehingga menghasilkan sebuah gambaran sebagai jawaban dari rumusan masalah yang dicari (Kriyantono, 2008).

\section{HASIL PENELITIAN DAN PEMBAHASAN}

Jagat media sosial twitter dihebohkan dengan munculnya akun-akun anonim. Informasi yang sensitif dan tak bisa didapatkan di media umum membuat akun anonim pengumbar info kebanjiran followers (pengikut), salah satunya adalah 
@ TrioMacan2000. Belum tentu semua informasi yang disampaikan itu benar, tetapi kicauannya beberapa kali mengundang komentar pejabat yang ikut terseret tweettweet akun ini makin gerah. Bahkan tidak sedikit dari mereka melaporkan akun anonim ini ke polisi.

Akun ini awalnya diberi nama "Ade Ayu Sasmita" @TrioMacan2000 namun nama ini berubah lagi dengan tagline "Suara Revolusi" dengan penjelasan "Akun pemerhati isu publik untuk pencerahan, perangi korupsi, kemunafikan pemimpin negeri. Provokasi untuk utamakan kejujuran dan anak yang cerdas dan merdeka. Nowhere but everywhere." Belakangan tagline akun ini berubah lagi menjadi “ Berani Jujur”.

Hasil penelitian secara keseluruhan, ternyata ada empat kategori analisis isi yang paling menonjol yang ditemukan dalam tweet @ Triomacan2000. Seperti diketahui kategori merupakan hal yang penting dalam penelitian analisi isi. Karena kategori digunakan sebagai acuan dalam menjawab permasalahan. Keempat kategori tersebut mengacu pada konsep bully yang telah dipaparkan sebelumnya (Rigby, 2005) yang kemudian disesuaikan dengan konsep cyberstalking (Bocij, 2004) yaitu keinginan untuk menyakiti, ketidakseimbangan kekuatan postingan, pengulangan atau repetisi, serta kesenangan yang dirasa oleh pelaku.
Berikut adalah pembahasan masingmasing kategori yang paling menonjol dalam tweet-tweet akun@Triomacan2000.

\section{Keinginan untuk Menyakiti}

Kategori cyberstalking yang dikaji adalah 'Keinginan untuk Menyakiti'. Dalam hal ini akun@TrioMacan2000 memposting hal-hal yang tidak menyenangkan, memanggil seseorang dengan julukan yang buruk, memposting kebohongan/rumor yang keliru mengenai seseorang, membuat orang lain tidak menyukai seseorang dan hal-hal semacamnya.

Hasil pengamatan, tweet-tweet dan gambar yang diposting di akun @ TrioMacan2000 sepanjang masa kampanye pileg, hampir semua memuat tentang hal-hal yang tidak menyenangkan tentang calon presiden RI terutama capres dari Partai Demokrasi Indonesia Perjuangan (PDIP), Joko Widodo (Jokowi).

Sebagian besar tweetnya, akun ini berkali-kali menyebut Jokowi sebagai "Pembohong". Jokowi juga dianggap tidak layak bagi rakyat Jakarta, jongos mafia Cina, menghianati beberapa tokoh di antaranya calon presiden dari partai Gerindra, Prabowo Subianto dan juga Jokowi dianggap tidak loyal kepada Megawati, Jusuf Kalla, dan bangsa/negara.

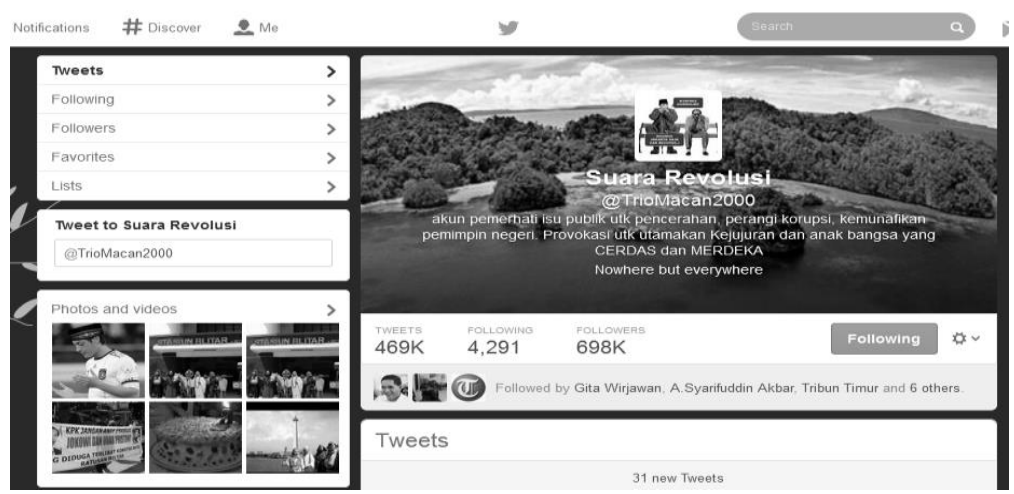

Sumber: Twitter.com/Suara Reformasi@TrioMacan2000.

Gambar 1

Akun Suara Revolusi @ TrioMacan2000, Maret 2014. 
Tabel 1

Kategori Cyberstalking yang Paling Menonjol dalam Isi Pesan (Tweet) Akun @TrioMacan2000

\begin{tabular}{|c|c|c|}
\hline No. & Kategori & Keterangan \\
\hline 1. & Keinginan untuk menyakiti & $\begin{array}{l}\text { Memposting hal-hal yang tidak menyenangkan, } \\
\text { memanggil seseorang dengan julukan yang buruk; } \\
\text { Memposting kebohongan/rumor yang keliru mengenai } \\
\text { seseorang, membuat orang lain tidak menyukai } \\
\text { seseorang dan hal-hal semacamnya. }\end{array}$ \\
\hline 2. & $\begin{array}{l}\text { Ketidakseimbangan } \\
\text { kekuatan }\end{array}$ & $\begin{array}{l}\text { Postingan isi pesan (tweet) yang tidak setara atau tidak } \\
\text { seimbang di mana didominasi oleh para pelaku dan } \\
\text { orang-orang yang mendukung pelaku bully. }\end{array}$ \\
\hline 3. & Pengulangan atau repetisi & $\begin{array}{l}\text { Isi pesan (tweet) yang mengandung bullying tidak } \\
\text { dimaksudkan sebagai peristiwa yang hanya terjadi } \\
\text { sekali saja, tapi juga repetitif atau cenderung diulangi. }\end{array}$ \\
\hline 4. & $\begin{array}{l}\text { Kesenangan yang dirasa } \\
\text { oleh pelaku }\end{array}$ & $\begin{array}{l}\text { Dalam isi pesan (tweet) terdapat kata-kata atau kalimat- } \\
\text { kalimat maupun gambar-gambar yang mengungkapkan } \\
\text { kesenangan yang dirasa pelaku dalam aktivitas } \\
\text { bullyingnya terhadap korban. Dan merasa senang jika } \\
\text { followersnya juga terpancing emosinya untuk juga } \\
\text { melakukan bully. }\end{array}$ \\
\hline
\end{tabular}

Sumber: Rigby (2005) dan Bocij (2004).
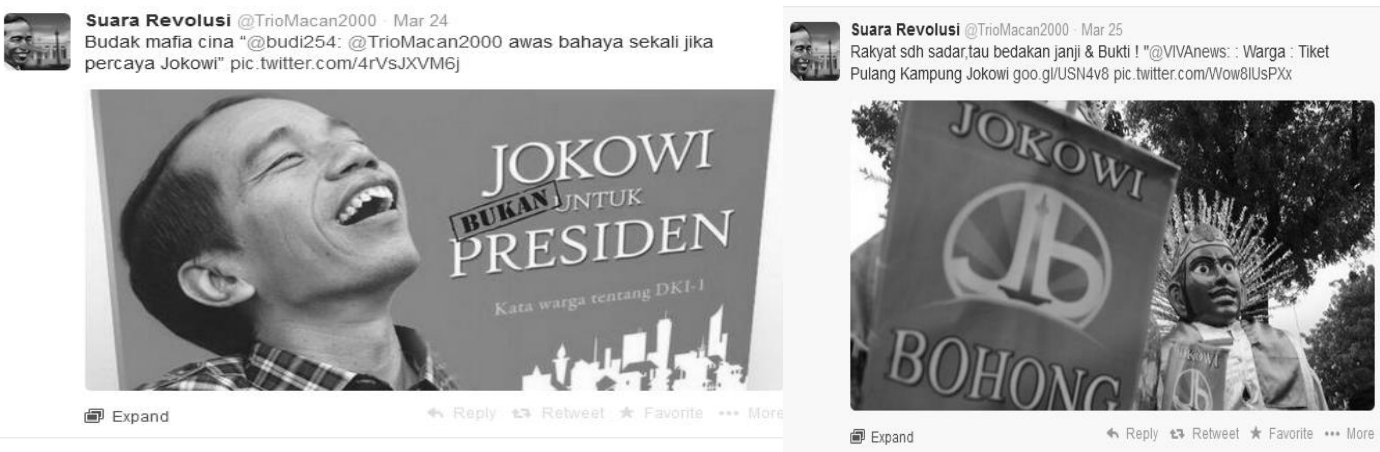

Sumber: Twitter.com/Suara Reformasi@TrioMacan2000

Gambar 2

Beberapa tweet/gambar @TrioMacan2000 yang menyerang capres PDIP, Jokowi

Akun ini juga memposting gambargambar yang secara tegas menilai Jokowi seorang pembohong dan merupakan budak Cina.

Fenomena ini berhubungan erat dengan apa yang dikemukakan oleh Coloroso (2006) bahwa bullying akan selalu melibatkan beberapa unsur, di antaranya 'keinginan untuk mencederai (desire to hurt)'. Dalam bullying, menurut Coloroso, tidak ada kecelakaan atau kekeliruan, tidak ada ketidaksengajaan dalam pengucilan korban.
Artinya, bulling memang dilakukan secara sengaja oleh akun @TrioMacan2000 bersama-sama para pendukungnya (followers) kepada korbannya, Jokowi. Tujuan bullying, menurut Coloroso, untuk membuat korban terluka karena kepedihan emosional dan menimbulkan rasa senang di hati sang pelaku saat menyaksikan penderitaan korbannya. Ini terlihat di banyak tweetnya, akun ini dengan sengaja menyerang Jokowi dan juga pendukung Jokowi. 
Jauh sebelumnya, akun @TrioMacan2000 sudah melakukan hal yang sama dengan menyerang tokoh-tokoh terkenal lainnya. Akun anonim ini semakin menjadi bahan perdebatan, tidak hanya di jejaring sosial, media online, dan televisi, tetapi juga di media massa internasional. Bukan baru kali ini saja ketika Jokowi dicalonkan oleh PDIP sebagai capres dalam Pemilu 2014 dibully. Namun jauh sebelumnya, akun ini sudah melakukan hal yang sama.

Data yang dikemukakan akun ini diakui sejumlah pihak tidak semuanya benar. Namun, dengan terang-terangan akun ini mengandung tujuan untuk menjatuhkan wibawa korban-korban yang menjadi bahan bullying mereka, terutama Jokowi. Ini sejalan dengan yang dikemukakan Olweus (2005) bahwa tindakan negatif yang termasuk dalam bullying antara lain mengatakan hal yang tidak menyenangkan atau memanggil seseorang dengan julukan yang buruk dan mengatakan kebohongan atau rumor yang keliru mengenai seseorang.

Hal ini dapat disebut dengan sebuah kejahatan. seperti yang dipaparkan sebuah hasil penelitian yang dilakukan Jaishankar dan Sankary (2013) berjudul "Cyber Stalking: A Global Menace in the Information Super Highway." Hasil penelitian ini menyebutkan bahwa cyberstalking merupakan bentuk baru kejahatan yang terjadi di dunia maya. Korban akan diikuti dan dikejar secara online. Privasi mereka diserang, setiap gerakan mereka diawasi. Ini adalah bentuk pelecehan yang dapat mengganggu kehidupan korban dan meninggalkan mereka merasa sangat takut dan terancam. Sementara itu, Bocij (2003) dalam artikelnya berjudul "Victims of Cyberstalking: An Exploratory Study of Harassment Perpetrated via The Internet" mengatakan bahwa cyberstalking harus dilihat sebagai bentuk baru dari perilaku menyimpang yang dapat dibedakan bullying konvensional.

\section{Ketidakseimbangan Kekuatan Postingan}

Konsep cyberstalking yang juga dikaji adalah 'Ketidakseimbangan Kekuatan Postingan'. Pada kategori ini, isi pesan (tweet) dan gambar yang diposting tidak setara atau tidak seimbang di mana didominasi oleh para pelaku dan orang-orang yang mendukung pelaku bullying.

Meski demikian, masih ada juga pesanpesan yang melakukan pembelaan terhadap korban bully, namun jumlahnya relatif sangat sedikit, tidak sebanding dengan pelaku dan pendukung bully. Seperti yang disampaikan akun dengan nama@SyahudinKC2 yang menuliskan pesan bahwa apa pun kata orang (seperti kejelekan-kejelekan yang disampaikan oleh akun Trio Macan 2000), tetapi dia tidak akan terpengaruh dan tetap akan memilih Jokowi. Tweet ini kemudian dibalas oleh @TrioMacan2000, bahwa silahkan saja memilih Jokowi karena hal itu merupakan hak konstitusi siapa saja. Sementara itu, akun dengan nama @Yusuf_Mansur mentweet pesan yang intinya mengungkapkan bahwa semua calon presiden adalah orang-orang yang hebat, kalaupun ada kekurangannya, akun ini menulis biarlah doa kita semua yang akan menjaga mereka semua. Tweet ini kemudian di retweet oleh akun Suara Revolusi @TrioMacan2000 dengan kalimat: “Ampuun ustaz..."

Unsur bullying lainnya yang dikemukakan oleh Coloroso (2006) juga berhubungan erat dengan hasil penelitian di atas, yaitu ketidakseimbangan kekuatan atau imbalance power. Pelaku bullying bisa saja orang yang lebih tua, lebih besar, lebih kuat, lebih mahir secara verbal, lebih tinggi secara status sosial, atau berasal dari ras yang berbeda, maupun dari segi jumlah pelaku kepada korban. Hal ini terlihat dari hampir keseluruhan isi pesan dan gambar pada akun @ Trio Macan 2000, melakukan bullying pada Jokowi. Aftab (Rahayu, 2012) mengungkapkan bahwa ada tiga macam metode cyberbullying, yaitu direct attacks (pesan-pesan dikirimkan secara langsung ke korban), posted and public attacks (dirancang untuk mempermalukan target dengan memposting atau menyebarkan informasi atau gambar-gambar yang memalukan ke publik), dan cyberbullying by proxy (memanfaatkan orang lain untuk membantu mengganggu 
korban, baik dengan sepengetahuan orang lain tersebut atau tidak). Ketiga metode ini dipraktikkan akun Trio Macan 2000 dalam memperlakukan korbannya.

\section{Pengulangan atau Repetisi}

Pengulangan atau repesisi merupakan konsep bullying berikutnya yang dikaji. Dari sekian banyak tweet dan gambar yang diposting pada akun @TrioMacan2000, selama tiga minggu, dapat disimpulkan bahwa baik administrator maupun followers yang mendukung akun ini kerap mengulangngulang tweet-tweet yang memojokkan Jokowi seperti jongos mafia Cina, pembohong, presiden boneka, dan lain sebagainya.

Beberapa gambar Jokowi yang diubah bagian matanya menjadi sipit menunjukkan bahwa tokoh ini diidentikkan dengan orang Cina atau sebagai antek-anteknya.

Akun twitter lainnya dengan nama Suara Rakyat @burunghantu1913 disebutsebut merupakan akun kembaran dari Trio Macan 2000. Akun Suara Rakyat dengan rutin membekingi akun Suara Reformasi. Hal ini terlihat dari kicauan-kicauannya yang juga menyerang orang yang sama dalam tweettweet mereka secara berulang-ulang. Di samping itu, saat akun Suara Rakyat berkicau menyerang Jokowi, tweet-tweet tersebut juga kemudian diretweet kembali oleh akun Suara Reformasi.

Mengamati sepak terjang akun @TrioMacan2000 yang bukan baru saat Pemilu 2014 saja mulai beraksi namun sejak beberapa tahun terakhir, dapat disimpulkan bahwa aksi bullying melalui media sosial semakin sulit dicegah. Apalagi hal tersebut tidak saja dilakukan satu dua kali tetapi berulang-ulang. Menurut Hinduja dan Patchin (2010), ada dua tantangan yang membuat aksi cyberbullying sulit untuk dicegah yaitu banyak orang tidak melihat bahaya atau dampak serius dari cyberbullying ini. Hal ini terjadi karena orang menganggap ada bentuk aksi agresi atau penyerangan yang lain yang lebih serius daripada cyberbullying. Tantangan yang lain berkaitan dengan siapa yang akan bertanggungjawab terhadap penyalahgunaan teknologi.
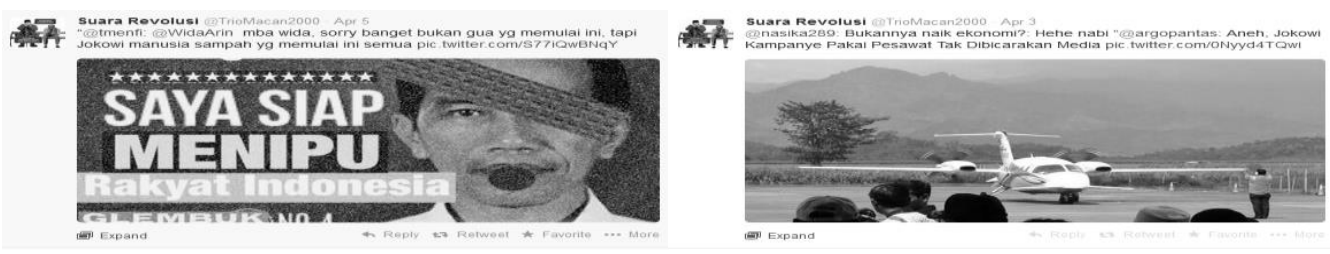

Sumber: Twitter.com/Suara Reformasi@TrioMacan2000.

\section{Gambar 3}

\section{Gambar dan tweet pada akun @ TrioMacan2000 yang membully capres PDIP, Jokowi}

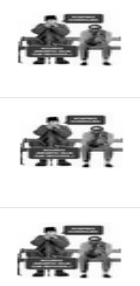

Suara Revolusi@TrioMacan2000-Apr 5

Poknya jgn jokowi, jongos mafia cina dan pembohong itu "@fauzifatur (0) TrioMacan2000 kamu kenapa to min benci amat sama jokowow, ntar cinta Expand

Suara Revolusi TrioMacan2000-Apr 3

Investasi mafia cina ke jokowi sdh belasan triliun @PUTRIEbatavia: Back to tukang mebel donk "Warga Usir Jokowi Dari Jakarta@okezonenews Expand Suara Revolusi@TrioMacan2000 14h NEGARA Adalah para majikan jokowi ! chirpstory.com/li/192074 Expand

Sumber: Twitter.com/Suara Reformasi@TrioMacan2000.

\section{Gambar 4}

Tweet-tweet pada akun@TrioMacan2000 yang menyerang capres PDIP, Jokowi (Tweet-tweet ini terus diulang-ulang hampir setiap hari) 
Suara Rakyat @burunghantu1913-16h

46. Manusia licik dan khianat kayak Jokowi ini dipuja2 oleh pasukan nasi

bungkus dan jongos2 mafia cina. Dia menipu rakyat jakarta, solo dst

Expand

Retweeted by Suara Revolusi

Suara Rakyat @burunghantu1913-16h

45. Program2 HUT, undang selebritis dunia, festival keraton se dunia berbiaya

30 miliar dari APBD DKI adlh utk kepentingan pribadi Jokowi !

Expand

Sumber: Twitter.com/Suara Reformasi@TrioMacan2000.

\section{Gambar 5 \\ Tweet-tweet akun Suara Rakyat @burunghantu1913 yang membeking akun @ TrioMacan2000 untuk menyerang capres PDIP, Jokowi}

Meski telah beberapa kali melakukan bullying terhadap tokoh-tokoh penting di negara ini yang kemudian dilaporkan ke polisi, namun kasus akun Trio Macan 2000 ini tidak dapat diungkap dengan mudah. Salah satunya karena sulitnya dilacak pemilik akun tersebut yang sebenarnya, sehingga kegiatan membully seseorang masih terus dilakukan berulang-ulang dengan mengatasnamakan sebuah pencerahan.

Pemilik akun ini bersedia mengaku sebagai pemilik akun yang namanya ditulis sebagai 'Ade Ayu Sasmita' kepada Tempo, tahun 2012. Dalam dua kali pertemuan dengan Tempo, dia mengaku bekerja sebagai konsultan politik, hukum, dan bisnis (Bagja dan Pramono, 2012). Analoginya, admin @TrioMacan2000 adalah para pengumpul berita tentang sebuah data mentah. Data ini diperoleh berdasarkan investigasi di lapangan (wartawan atau kawan media). Sementara itu, ada juga yang bertugas menginput data tersebut ke dalam kultweet milik @TrioMacan2000.

Hasil penelitian ini berhubungan erat dengan apa yang disampaikan seorang profesor bidang etika teknologi, Lamber Royakkers bahwa cyberstalking adalah bentuk penyerangan mental, di mana pelaku berulang kali (repeatedly), unwantedly (secara tidak diinginkan), dan disruptively (memecah belah, mengacaukan) menerobos masuk ke dalam dunia kehidupan dari korban (baik masih memiliki hubungan atau tidak), dengan motif secara langsung atau tidak langsung menyebabkan kekerasan mental. Sedangkan cyberangels, sebuah organisasi nonprofit internasional yang mengawasi kejahatan warga tanpa bersenjata, menyebutkan bahwa cyberstalking selalu dilakukan dengan penuh kedengkian, direncanakan terlebih dahulu, dilakukan secara berulang-ulang, mengakibatkan kesusahan pada korban, penuh obsesi, dendam, tanpa tujuan yang jelas, mengabaikan peringatan untuk berhenti, pelecehan, dan ancaman (Bocij, 2004).

\section{Kesenangan yang Dirasa Pelaku}

Kategori terakhir dari cyberstalking yang diteliti dalam penelitian ini adalah kesenangan yang dirasa pelaku. Dalam isi pesan (tweet) terdapat kata-kata atau kalimatkalimat juga gambar-gambar yang mengungkapkan kesenangan yang dirasa pelaku dalam aktivitas bullyingnya terhadap seseorang.

Penelitian ini tampak jelas menunjukkan ada kesenangan tersendiri yang dirasakan pelaku bullying saat berkicau atau memposting gambar yang menyudutkan korbannya. Seperti gambar 6, di mana Jokowi digambarkan sebagai tokoh gabungan Gatot Koco dan Superman. Pada gambar tersebut, 
Jokowi juga digambarkan sebagai satriopiningit dari Solo.

Indikasi kesenangan yang dirasakan pelaku saat melakukan bullying terhadap korban terlihat dari kata-kata yang digunakan dalam kicauannya selalu menggunakan kata-

kata hiperbola yang tujuannya mengejek serta diikuti dengan candaan tertawa (hehehe...) di akhir kalimat. Seperti yang terlihat dari beberapa tweet akun @TrioMacan2000 berikut ini:

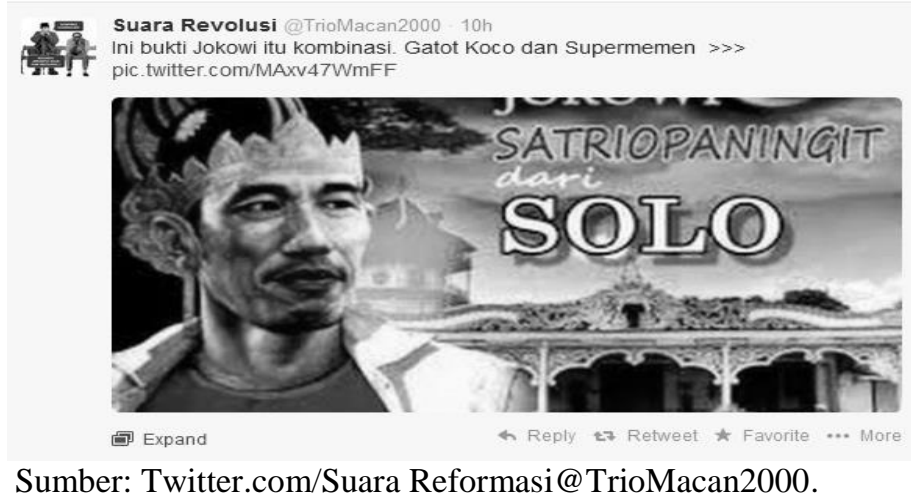

Sumber: Twitter.com/Suara Reformasi@TrioMacan2000.

\section{Gambar 6}

Gambar dan tweet pada akun @ TrioMacan2000 yang menggambarkan kesenangan pelaku bullying saat menyerang korban capres PDIP, Jokowi

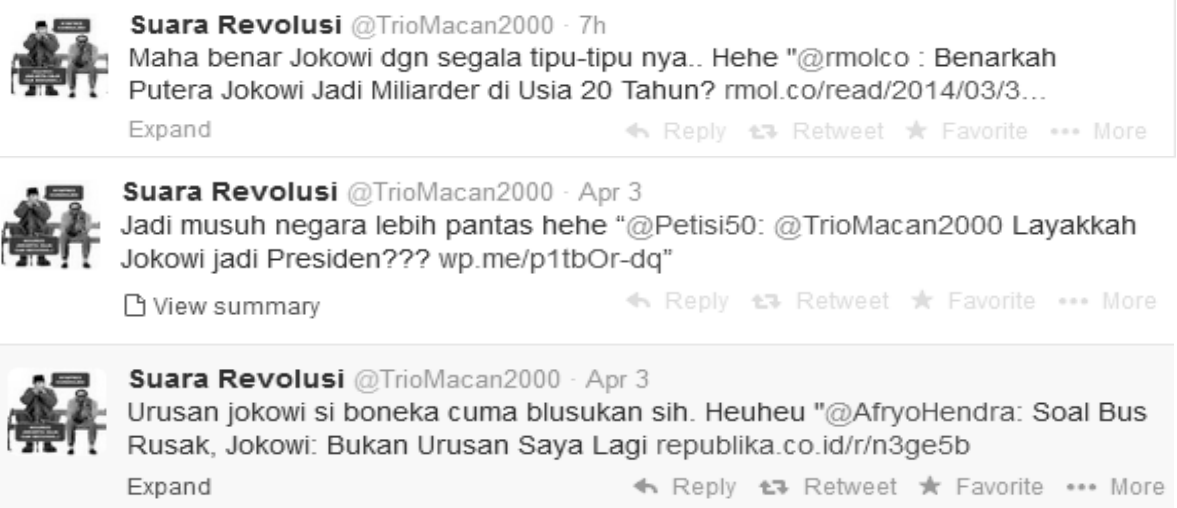

Sumber: Twitter.com/Suara Reformasi@TrioMacan2000.

\section{Gambar 7}

Beberapa tweet pada akun @TrioMacan2000 yang menggambarkan kesenangan pelaku bullying saat menyerang korban capres PDIP, Jokowi

Jokowi bukan merupakan satu-satunya calon presiden yang diejek dan diserang dalam akun twitter Trio Macan 2000, calon lainnya yaitu Aburizal Bakrie dari Partai Golkar juga mendapatkan perlakuan yang sama, meski dalam jumlah bullying yang relatif sangat sedikit.

Kesenangan yang dirasa pelaku bullying tidak hanya ditunjukkan dengan mentweet atau memposting gambar-gambar korban bullying yang kemudian ditertawakan, tetapi pelaku juga tampak senang jika para followersnya menjadi marah dan ikut melakukan bullying korban-korbannya. Sebagai contoh saat foto ARB dengan Marcela diunggah di akun Trio Macan 2000, sejumlah followers dengan spontan memberi komen yang menyudutkan. Gambar itu pun berkali-kali di retweet dengan tujuan untuk menyebarkan gambar tersebut agar semakin banyak orang yang melihatnya dan memberi komentar. 
Sebuah riset yang dilakukan Claire Hardaker, seorang ahli linguistik dari Universitas Lancaster berusaha mengungkap penyebab bullying di media sosial. Berdasarkan 4.000 kasus bullying, ia menarik kesimpulan bahwa kebosanan (boredom) berada di balik banyak peristiwa bullying. Metode paling banyak yang digunakan pelaku bullying di situs facebook dan twitter adalah memicu kemarahan untuk kesenangan diri mereka sendiri. Ini artinya pelaku memang sengaja memancing pengguna media sosial untuk marah agar mereka merasa senang. Para pendukung pelaku bullying mengatakan bahwa perilaku mereka tersebut tidak lain adalah humor dan kenakalan biasa serta kebebasan berbicara, namun sebenarnya hal tersebut adalah pelecehan dan hate speech. Pelaku beroperasi karena merasa memiliki kekuasaan, mencari hiburan, kebosanan dan balas dendam, terlebih hal ini dilayani dengan baik oleh adanya anonimitas di internet (Dailymail, 2013).

Penyebab terjadinya cyberstalking bisa karena dendam, kemarahan, atau perasaan frustrasi. Bisa juga karena pelaku memang tidak memunyai pekerjaan, iseng, dan ingin mencari keributan. Atau bisa jadi, pelaku adalah orang-orang yang di kehidupan nyata termasuk golongan 'tidak dianggap' atau tidak punya kekuatan. Dengan melakukan bullying, mereka merasakan bagaimana rasanya menjadi 'orang yang berkuasa'. Atau bisa juga karena dibayar. Cyberstalkers ini mencoba merusak reputasi korban dengan memengaruhi orang lain. Mereka dapat memposting informasi palsu tentang target di situs web, bisa dengan membuat website sendiri, blog atau halaman pengguna untuk tujuan ini. Mereka memposting tuduhan tentang korban di newsgroup, chat room, atau situs lain yang memungkinkan kontribusi publik, dan mendorong orang lain untuk melecehkan korban, seperti yang dilakukan akun @TrioMacan2000.

Cyberstalkers kerap mencoba untuk melibatkan pihak ketiga dalam pelecehan tersebut. Mereka mungkin mengklaim korban telah merugikan mereka atau keluarganya dalam beberapa cara. Mereka akan memanipulasi informasi untuk mendorong orang lain untuk bergabung dan melawan target. Cyberstalker juga kadang mengklaim bahwa korban yang melecehkan dirinya. Bocij (2004) menulis bahwa fenomena ini telah dicatat dalam sejumlah kasus terkenal. Apa yang dikatakan oleh Paul ini dapat dilihat juga pada akun Trio Macan 2000, di mana orang di balik akun ini akan selalu membela diri jika ada orang lain yang menuduh mereka membenci Jokowi. Salah satu contoh tweet Trio macan 2000 tanggal 5 April 2014 berbunyi: "mba wida, sorry banget bukan gua yang memulai, tapi Jokowi manusia sampah yang memulai semua..."

Fenomena ini berhubungan erat dengan apa yang dikemukakan Mental Profiling of Digital Criminals (Valentino, 2013) bahwa motivasi cyberstalker antara lain adalah iri hati, tidak mau kalah, merasa diri hebat, obsesi patologis (profesional atau seksual), tidak ingin melihat orang lain berhasil atau bahagia, niat untuk mengintimidasi dan menyebabkan orang lain merasa rendah diri, takut dan sebagainya, merasa yakin akan selalu lolos karena anonimitas, melakukan intimidasi untuk keuntungan keuangan atau persaingan usaha, serta balas dendam atas penolakan dirasakan atau dibayangkan.

Hingga di sini, didapati problem besar kebebasan berpendapat dalam arena media sosial. Sudibyo (2014) berpendapat, kebebasan berpendapat itu belum sepenuhnya dilandasi penghormatan terhadap hak-hak orang lain dan nilai-nilai keadaban publik. Dalam berbagai isu, media sosial tampak digunakan sebagai sarana menghujat, mencaci maki atau merendahkan pihak tertentu. Dalam media sosial, ditemukan tidak sekadar kritik yang argumentatif, tetapi juga kritik yang apriori dan kasar. Dengan mudahnya satu pihak menghakimi pihak lain tanpa ada mekanisme klarifikasi dan umpan balik. Hiperaktualitas dan interaktivitas sebagai keunggulan komparatif media sosial telah mendorong penggunanya untuk melontarkan kata pernyataan spontan, otomatis, dan tanpa berpikir panjang. Gairah dan suasana diskusi di media sosial mengondisikan penggunanya 
berbicara sesegera mungkin dan seaktual mungkin.

Hannah Arendt dalam Sudibyo (2014) mengatakan, kita kehilangan kemampuan untuk berdialog dengan diri sendiri dan mempertimbangkan kata hati sebelum bertindak dan berucap. Sehingga tidak mampu menenggangnasib dan perasaan orang lain, tidak sekadar mengikuti naluri egoistik anarkis.

\section{PENUTUP}

\section{Simpulan}

Sebagian besar tweet dan gambar yang diposting di akun @TrioMacan2000 pada masa kampanye pemilihan legislatif masuk ke dalam seluruh kategori cyberstalking yang diteliti, yaitu keinginan untuk menyakiti, ketidakseimbangan kekuatan postingan, pengulangan atau repetisi, serta kesenangan yang dirasa oleh pelaku.

Tweet dan gambar pada akun ini hampir semua memuat hal-hal yang tidak menyenangkan tentang calon presiden RI, terutama capres dari PDIP, Jokowi. Jokowi disebut sebagai pembohong, tidak layak, jongos mafia Cina, dan penghianat bangsa. Isi pesan (tweet) dan gambar yang diposting juga tidak seimbang di mana didominasi para pelaku dan orang-orang yang mendukung perilaku bullying. Meski demikian, masih ada juga pesan-pesan yang melakukan pembelaan terhadap korban Jokowi meski jumlahnya relatif sangat sedikit.

Administrator dan followers yang mendukung akun ini juga kerap mengulangngulang tweet-tweet dan gambar yang memojokkan Jokowi seperti jongos mafia Cina, pembohong, presiden boneka, dan lain sebagainya. Hasil penelitian ini menunjukkan, tampak jelas ada kesenangan tersendiri yang dirasakan oleh pelaku bullying saat berkicau atau memposting gambar yang menyudutkan Jokowi. Indikasi kesenangan yang dirasakan pelaku terhadap korban terlihat dari kata-kata yang digunakan yang tujuannya mengejek dan menyerang korban disertai dengan candaan. Juga dengan banyaknya followers yang ikut tersulut emosinya untuk melakukan bullying hanya karena dipicu isi pesan dan gambar yang diposting akun ini.

\section{Saran}

Perilaku cyberbullying ataupun cyberstalking dipastikan memiliki dampak yang sangat merugikan dan berbahaya bagi korban. Karena itu, kegiatan tidak pantas dijadikan alasan sebagai cara dalam kebebasan berekspresi dan mengemukakan pendapat. Kebebasan berekspresi sepatutnya tidak digunakan untuk merugikan orang lain. Di samping itu, gerakan moral memerangi cyberbullying baik bagi anak-anak, remaja, maupun cyberstalking bagi orang dewasa harus terus digalakkan karena hal tersebut sangat merugikan dan merusak mental para korban. Begitu juga bagi pengguna media sosial, apa pun itu bentuknya, agar dapat bijak, beretika, dan tidak terprovokasi oleh akun-akun anonim untuk ikut serta melakukan bullying terhadap pihak-pihak tertentu.

\section{DAFTAR PUSTAKA}

\section{Buku:}

Bocij, Paul. (2004). Cyberstalking: Harassment in the Internet Age and How to Protect Your Family. Praeger.9,10,14.

Coloroso, Barbara. (2006). Penindas, Tertindas, dan Penonton; Resep Memutus Rantai Kekerasan Anak dari Prasekolah hingga SMU. Jakarta: Serambi Ilmu Pustaka.

Kholil, Syukur. (2006). Metodologi Penelitian. Bandung: Citapusaka Media.

Kriyantono, Rachmat. (2008). Teknis Praktis Riset Komunikasi; Disertai Contoh Praktis Riset Media, Public Relations, Advertising, Komunikasi Organisasi, Komunikasi Pemasaran. Jakarta: Kencana. 
Rigby, Ken. (2005). The Anti-Bullying and Teasing Book. Australia: Gryphon House, Inc.

\section{Jurnal:}

Rahayu. (2012). Cyberbullying sebagai Dampak Negatif Penggunaan Teknologi Informasi. Journal of Information Systems, 8 (1), April, hal. 35.

\section{Surat Kabar/Majalah:}

Sudibyo, Agus. (2014). Media Sosial dan Keberadaan Kita. Kompas, 28 Januari, hal. 5.

Thompson, Clive. (2009). "I'm So Totally, Digitally Close to You". The New York Times Magazine, 5 September, pp.15.

\section{Internet:}

Admin. (2014). Cyberbulling Menjadi Sorotan Dibalik Kematian Charlotte Dawson. Tersedia di: <http://kabarkampus.com/2014/02/cybe rbullying-menjadi-sorotan-dibalikkematian-charlotte-dawson/>.Diakses 27 Maret 2014.

Bagja dan Pramono. (2012). Siapa Pemilik Akun Twitter Triomacan2000. Tersedia di:

<http://www.tempo.co/read/news/2012/ 05/23/078405636/Siapa-Pemilik-Akun-

Twitter-Triomacan2000>.Diakses 27 Maret 2014.

Bocij, Paul. (2003). Victims of Cyberstalking: An Exploratory Study of Harassment Perpetrated via The Internet. Volume 8, Number 10 - 6 October 2003. Tersedia di:

http://firstmonday.org/ojs/index.php/fm /article/view/1086/1006. Diakses 7 Mei 2014.

Beritakaltara. (2014). Dahlan Iskan Di-Bully, Perusda Listrik Kaltim Dibawa-bawa .Tersedia <http://beritakaltara.com/?p=1704>

Diakses 27 Maret 2014.

Cyberbullying126e27. (2012). Cyberbullying. Tersedia

di: <http://cyberbullying126e27.blogspot.c om/>.Diakses 26 maret 2014.

Dailymail. (2013). Sebab Terjadinya Cyberbullying dan Trolling di Media Sosial. Tersedia di: http://ictwatch.com/internetsehat/2013/ 07/08/sebab-terjadinya-cyberbullyingdan-trolling-di-media-sosial/.Diakses 27 Maret 2014.

D'Monte, Leslie. (29April, 2009). Swine flu's tweet tweet causes online flutter. Tersedia di: <http://www.businessstandard.com/article/technology/swineflu-s-tweet-tweet-causes-online-flutter109042900097_1.html>.Diakses, 5 Maret 2014.

Harvey, Judge David. (2003). Cyberstalking and Internet Harassment: What The Law Can Do. Tersedia di: http://www.netsafe.org.nz/Doc_Library/ netsafepapers_davidharvey_cyberstalki ng.pdf.Diakses 28 Mei 2014.

Hensler, Nancy Felicity dan McGinnis. (2008). Cyberstalking Victimization: Impact and Coping Responses in a National University Sample. Dissertation the Faculty of the Graduate School of the University of Maryland. Tersedia di: <http://drum.lib.umd.edu/bitstream/190 3/8206/1/umi-umd-5402.pdf>. Diakses 28 Mei 2014.

Jaishankar, K. dan V. Uma Sankary. (2012). Cyber Stalking: A Global Menace in the Information Super Highway. Tersedia di: <http://www.erces.com/ journal/ articles/ archives/ volume2/v03/v02.htm>. Diakses 7 Mei 2014.

Mohamad, Ardyan. (2013). Di 5 Media Sosial Ini Orang Indonesia Pengguna Terbesar Dunia. Tersedia di: <http://www.merdeka.com/uang/di-5media-sosial-ini-orang-indonesiapengguna-terbesar-dunia.html> Diakses 27 Maret 2014.

Olweus, Dan. (2005). Bullying Intervention Strategies That Work. Tersedia di: $<$ http://www.educationworld.com/a_iss 
ues/issues/issues103.shtml>. Diakses 27 Maret 2014.

Putra. Yudha Manggala P. (2013). Pertumbuhan Twitter Lebih Kencang dari Facebook. Tersedia di: <http://www.republika.co.id/berita/tren dtek/aplikasi/13/01/30/mhf4fbpertumbuhan-Twitter-lebih-kencangdari-facebook>.Diakses 27 Maret 2014. Susanti,Inda. (2006). Bullying Bikin Anak Depresi dan Bunuh Diri. Tersedia di: <http://www.kpai.go.id/mn_access.php ?to=2-artikel\&sub=kpai_2artikel_bd.html >. Diakses 27 Maret 2014.

Twitter.com/Suara

Reformasi@TrioMacan2000. Tersedia di:

$<$ https://Twitter.com/Suara\%20Reforma si@TrioMacan2000>. Diakses 5 Maret - 16 April 2014.

Valentino. (2013). Cyberbullying dan Cyberstalking dalam Pemahaman Sederhana. Tersedia di: $<$ http://teknologi.kompasiana.com/inter net/2013/01/25/cyberbullying-dancyberstalking-dalam-pemahamansederhana--522828.html>. Diakses 6 Mei 2014. 